\title{
Learning Program Development "FindBoiliQ" (Physics Industry Boiler Base Inquiry) to Increase Learning Achievement by Reduce Impact of Physics Abstraction on High School Students
}

\author{
Pengembangan Program Pembelajaran "FindBoiliQ" (Fisika Industri \\ BoilerBerbasis Inkuiri) Untuk Meningkatkan Prestasi Belajar melalui Penurunan \\ Dampak Abstraksi Fisika pada Siswa SMA
}

\author{
Acep Musliman \\ Program Studi Pendididkan Matematika Ilmu Pengetahuan Alam (MIPA) \\ Fakultas Pasca Sarjana - Universitas Indraprasta PGRI \\ Jl. Nangka No. 58 C. Tanjung Barat Jagakarsa, Jakarta Selatan 12530
}

\section{Received: March 31, 2018 \\ Revised: July 22, 2018 \\ Accepted: August 1, 2018}

\begin{abstract}
The "FindBoiliQ" learning program is a high school physics learning program utilizing the boiler industry (steam engine) as an inquiry-based learning object as a learning method. The research methodology in this study is a research development (Research and Development, abbreviated $\mathrm{R} \& \mathrm{D}$ ) in the field of education. This study focuses on the development of learning programs "FindBoiliQ" is short for Physics, Industrial-Boiler and InQuiry, also is a combination of the words "Find, Boil, and iQ" The meaning contained in the 3 words of physics as high school subjects, boiler industry is the object of learning, and Inquiry is a method of learning, all three have different roles and functions to form a physics learning program that can improve student achievement. "FindBoiliQ" has characteristics based on the above word equivalents, ie; electing the concepts of physics that are considered complex given the stimulus in the form of activity visits to the object of learning to observe the implementation of physics concepts in the real world so that students have a response in the form of an increase in their curiosity on the concept that is considered complex. The strong curiosity of students is further enhanced by the interactive Multimedia (MMI) of learning that is able to imagine the concept of the abstract to something more real. The results of the "FindBoliQ" implementation in experimental class students are able to improve concept comprehension better than the students' understanding of the concept of control class with regular learning on the same concept.
\end{abstract}

Keywords: FindBoiliQ, Industrial-Boiler, MMI, Inquiry

(*) Corresponding Author: ～acep_matsci@yahoo.com smartphone: 081295497282.

How to Cite: Musliman, A. (2018). Learning program development "findboiliq" (physics industry boiler base inquiry) to increase learning achievement by reduce impact of physics abstraction on high school students. Formatif: Jurnal Ilmiah Pendidikan MIPA, $8 \quad$ (2): 129-142. http://dx.doi.org/10.30998/formatif.v8i2.2407

\section{PENDAHULUAN}

Fokus perhatian utama semua cabang ilmu pengetahuan alam, termasuk fisika, secara umum dipandang sebagai kondisi dari wujud dan penampakan komplek yang dapat dideteksi oleh indera-indera manusia. Khususnya fisika, erat sekali berhubungan dengan 
Formatif: Jurnal Ilmiah Pendidikan MIPA

Vol. 8, No. 2, Agustus 2018, pp. 129-142

p-ISSN: 2088-351X

e-ISSN: 2502-5457

DOI: http://dx.doi.org/10.30998/formatif.v8i2.2407

materi dan energi, dengan hukum-hukum mengatur gerakan partikel dan gelombang, interaksi antar partikel, dan sifat-sifat molekul, atom, dan inti atom, serta dengan sistemsistem berskala lebih besar (Tipler, 1991). Perhatian terhadap dimensi isi sebagai bagian pokok dari ilmu fisika cukup sulit untuk dapat dipahami siswa dalam proses pembelajaran secara konseptual, hal ini diakibatkan oleh kondisi dimana teori yang sulit ditunjukkan secara nyata dan lebih bersifat abstrak. Pengetahuan fisika terdiri atas banyak konsep dan prinsip yang pada umumnya sangat abstrak (Bhakti \& Napis, 2017). Selain itu, fisika sebagai ilmu merupakan landasan pengembangan teknologi sehingga teori fisika sangat membutuhkan tingkat kecermatan yang tinggi. Oleh karena itu, fisika berkembang dari ilmu yang bersifat kualitatif menjadi ilmu yang bersifat kuantitatif (Wospakrik, 1993). Pembelajran fisiska yang melibatkan siswa dalam aspek nyata melalui pendekatan ilmiah, tentunya akan mampu memberikan fondasi kepada siswa untuk memahmi dan mengetahui bagaimana ilmu fisika dikembangkan, seperti para fisikawan mengembangkan hal serupa. Dari sisi proses, fisikawan menentukan variabel-variabel yang diteliti, menentukan "apa masalahnya", mengembangkan kerangka kerja teoretik, dan akhirnya membangun sebuah model untuk menjelaskan suatu fenomena (Redish, 2004).

Fisika menjadi dasar untuk banyak teknologi karena berkaitan dengan aspek materi dan energi serta hukum-hukum yang mengaturnya. Sebagian besar teknologi peralatan dan teknik yang digunakan oleh ilmuwan lain awalnya dikembangkan oleh fisikawan, misalnya sinar-X, ultrasonografi, dan Magnetic Resonance Imaging SCCC. Saat teknologi menjadi lebih komplek, keterkaitan teknologi dengan sains menjadi semakin kuat. Teknologi baru seringkali memerlukan pemahaman baru, penelitian baru seringkali memerlukan teknologi baru (Rutherford \& Ahlgren, 1990). Oleh karena itu, sangat tepat jika pembelajaran fisika ditingkat SMA juga didukung oleh hasil atau produk-produk teknologi yang dikembangkan dari konsep dasar fisika. Sebagai contoh adalah industri boiler yang dikenal secara awam adalah mesin uap yang dimiliki kelompok usaha industri Nani Wahyuni Industriest (NWI-Group) dan Sekolah Menengah Atas Islam (SMA Al-Azhar Harapan Indah) sebagai bagian daripada-nya cocok memanfaatkan industri tersebut sebagai objek belajar fisika.

Siswa dapat meningkatkan penguasaan konsep fisika apabila dilakukan kegiatan pembelajaran yang bermakna. Pembelajaran bermakna dalam pengetahuan fisika akan terwujud jika dilakukan melalui implemtasi metode ilmiah dan disertai penalaran pemikiran/kognitif terhadap data yang diperoleh maupun gejala alam yang diamati. Selain itu, rancangan pembelajaran berdasarkan metode ilmiah juga dapat mengembangkan kemampuan penalaran ilmiah dan keterampilan proses ilmiah siswa. Menurut Wenning (2011) siswa akan mudah menguasai konsep yang rumit dan abstrak jika disertai dengan contoh konkret, sesuai dengan pokok bahasan, dan mempraktekkan sendiri sebagai upaya penemuan konsep. Tugas guru bukan memberikan pengetahuan, melainkan menyiapkan situasi dan memberi stimulus kepada siswa untuk mendorong meningkatkan minat dan memotivasi siswa terhadap konsep.

\section{Pembelajaran Inquiry dan Multi Media Interaktif}

Model pembelajaran inquiry adalah pendekatan dengan pemberian tugas secara sistematis melalui promosi pengembangan keterampilan proses kognitif dan metode ilmiah untuk membuktikan hasil pengamatan secara sistematis dan komprehensif. Ketika mengajar menggunakan pendekatan Inquiry, siswa memiliki kesempatan untuk melakukan pengamatan, merumuskan/memprediksikan, mengumpulkan dan menganalisis data, mengembangkan prinsip-prinsip ilmiah, mensintesis hukum, dan membuat uji 
Formatif: Jurnal Ilmiah Pendidikan MIPA

Vol. 8, No. 2, Agustus 2018, pp. 129-142

p-ISSN: 2088-351X

e-ISSN: 2502-5457

DOI: http://dx.doi.org/10.30998/formatif.v8i2.2407

hipotesis untuk menghasilkan penjelasan (Wenning, 2011). Berbagai artikel yang ditulis oleh para peneliti terkemuka terkait dengan metode inquiry adalah menyiapkan kerangka kerja untuk setiap penugasan yang berorientasi pada pengamatan dangan cara tersebar dan acak.

Menurut Downey dalam Joyce (2003) menyatakan bahwa inti dari berpikir yang baik adalah kemampuan untuk memecahkan masalah. Dasar dari pemecahan masalah adalah kemampuan untuk belajar dalam situasi proses berpikir. Dengan demikian, hal ini dapat di implementasikan bahwa kepada siswa hendaknya diajarkan bagaimana belajar meliputi apa yang diajarkan, bagaimana hal itu diajarkan, jenis kondisi belajar, sehinga mereka mendapatkan pandangan baru. Salah satu yang termasuk dalam model pemrosesan informasi adalah model pembelajaran inquiry.

"Model pembelajaran inquiry adalah rangkaian kegiatan pembelajaran yang menekankan pada proses berpikir secara kritis dan analisis untuk mencari dan menemukan sendiri jawaban dari suatu masalah yang dipertanyakan" (Sanjaya, 2006). Menurut piaget dalam Mulyasa (2008) bahwa model pembelajaran inquiry adalah model pembelajaran yang mempersiapkan siswa pada situasi untuk melakukan eksperimen sendiri secara luas agar melihat apa yang terjadi, ingin melakukan sesuatu, mengajukan pertanyaan-pertanyaan, dan mencari jawabannya sendiri, serta menghubungkan penemuan yang satu dengan penemuan yang lain, membandingkan apa yang ditemukannya dengan yang ditemukan siswa lain.

Dengan memahami kedua pendapat di atas, maka dapat memberikan pandangan bahwa pembelajaran inquiry adalah model pembelajaran yang mempersiapkan siswa pada situasi untuk melakukan eksperimen sendiri sehingga dapat berpikir secara kritis untuk mencari dan menemukan jawaban dari suatu masalah yang dipertanyakan. Pembelajaran inquiry banyak dipengaruhi oleh aliran belajar kognitif, menurut aliran ini belajar pada hakikatnya adalah proses mental dan proses berpikir dengan memanfaatkan segala potensi yang dimiliki setiap individu secara optimal.

Di dalam pembelajaran, siswa akan melakukan aktivitas-aktivitas berpikir yang berupa memasukkan, menyimpan, dan menggunakan informasi. Aktivitas-aktivitas ini dikenal dengan pemrosesan informasi. Pandangan pemrosesan informasi awal tentang ingatan menggunakan komputer sebagai model, yakni pemrosesan informasi dilakukan untuk memperoleh informasi dan mengorganisasikannya dalam kaitannya dengan yang diketahui (encoding), menyimpan informasi (strorage), dan mengambil informasi ketika dibutuhkan (retrieval) yang keseluruhannya dipandu oleh proses-proses pengontrolan. Ahli pendidikan menyatakan bahwa bentuk-bentuk penyimpanan ini berupa simpanan jangka-pendek dan simpanan jangka-panjang. Akan tetapi, berdasarkan model pemrosesan informasi yang ia rumuskan, membagi penyimpanan ini menjadi ingatan sensoris, memori kerja (working memory), dan ingatan jangka panjang; ingatan sensoris merupakan pemrosesan pertama yang mentransformasi stimuli yang masuk menjadi informasi yang dapat dipahami, memori kerja merupakan "meja kerja" sistem ingatan yang mencakup penyimpanan sementara dan pemrosesan aktif yang mengkombinasikan informasi baru dengan pengetahuan dari ingatan jangka panjang untuk menyelesaikan masalah atau memahami sesuatu, ingatan jangka panjang menyimpan informasi yang sudah dipelajari dengan baik misalnya nomor identitas pribadi yang sudah dihafal. Berdasarkan pandangan ini, dapat disimpulkan bahwa kunci utama dalam pemrosesan informasi adalah memori kerja. Sebagai implikasinya, pengembangan program pembelajaran yang memanfaatkan simulasi atau Multimedia Interaktif (MMI) dalam program pembelajaran fisika SMA perlu memperhatikan sifat dan cara kerja memori kerja. 
Formatif: Jurnal Ilmiah Pendidikan MIPA

Vol. 8, No. 2, Agustus 2018, pp. 129-142

p-ISSN: 2088-351X

e-ISSN: 2502-5457

DOI: http://dx.doi.org/10.30998/formatif.v8i2.2407

Di dalam pembelajaran yang memanfaatkan MMI, permasalahan yang berkaitan dengan keterbatasan memori kerja adalah bagaimanakah membangun pemahaman kompleks yang mengintegrasikan informasi dari sumber-sumber visual (gambar, diagram, grafik, film) dan verbal (teks, ceramah). Woolfolk memberikan arahan: pastikan informasi-informasinya tersedia pada saat yang sama atau terfokus pada potonganpotongan kecil; berilah siswa banyak cara untuk memahami (gambar dan penjelasan), akan tetapi jangan menjejali memori kerja dengan cara mengemas informasi visual dan verbal bersama-sama dengan potongan-potongan yang seukuran "satu gigitan" (atau seukuran satu ingatan). Pernyataan ini kiranya dapat digunakan sebagai landasan dalam pengembangan program pembelajaran fisika SMA dengan metode inquiry learning dan pemanfaatan MMI sebagai media pembelajaran. Yaitu pembelajaran dengann pendekatan siswa sebagai pusat pembelajaran dengan melakukan langkah-langkah metode ilmiah dalam melakukan pembuktian konsep-konsep yang dipelajari sehingga mereka menemukan sendiri konsep dan pengetahuannya melalui pendampingan guru dan simulasi Multi Media interaktif.

\section{Industri Boiler}

Diawali dari konsep dan cara kerja boiler yang akan dijadikan objek belajar juga menjadi ilustrasi model multi media interktif yang akan dikembangkan sebagai media pembelajaran, terlebih dahulu harus ada sinkronisasi antara implementasi mesin dengan konsep fisika yang akan disampaikan. Konsep dan cara kerja boiler dapat dijelaskan secara sederhana dengan gambaran yang dapat dilihat pada Gambar 1 di bawah. Prinsip kerja boiler sebenarnya cukup sederhana sama seperti pada saat kita sedang mendidihkan air menggunakan panci. Proses pendidihan air tersebut akan selalu diiringi proses perpindahan panas yang melibatkan bahan bakar, udara, material wadah air, serta air itu sendiri. Proses perpindahan panas ini mencakup tiga jenis perpindahan panas yang sudah sangat kita kenal yakni konduksi, konveksi, dan radiasi.

Pada boiler pipa air di atas misalnya, sumber panas didapatkan dari pembakaran bahan bakar di dalam furnace. Energi panas ini sebagian akan terpancar secara radiasi ke pipa-pipa evaporator sehingga memanaskan pipa-pipa tersebut. Panas yang terserap oleh permukaan pipa akan secara konduksi berpindah ke sisi permukaan dalam pipa. Di dalam pipa, mengalir air yang terus-menerus menyerap panas tersebut. Proses penyebaran panas antar molekul air di dalam aliran ini terjadi secara konveksi. Perpindahan panas konveksi antar molekul air, seakan-akan menciptakan aliran fluida tersendiri terlepas dengan aliran air di dalam pipa-pipa boiler. Gerakan molekul air ini selanjutnya dimanfaatkan sebagai energy gerak yang akan mendorong/memutar turbin dan mengubahnya menjadi energy listrik. 
Formatif: Jurnal Ilmiah Pendidikan MIPA

Vol. 8, No. 2, Agustus 2018, pp. 129-142

p-ISSN: 2088-351X

e-ISSN: 2502-5457

DOI: http://dx.doi.org/10.30998/formatif.v8i2.2407

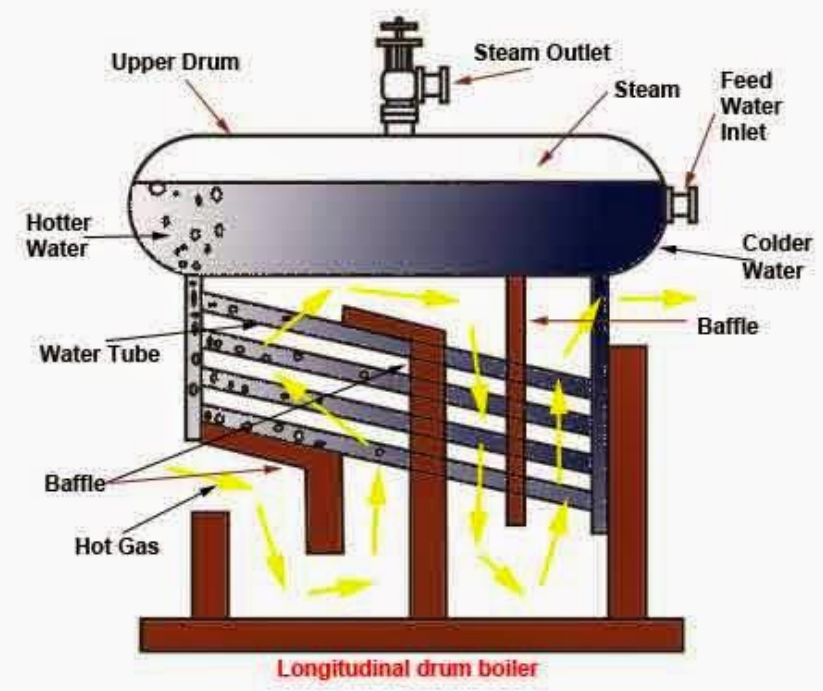

Gambar 1. Boiler dengan drum longitudinal

Prinsip dan cara kerja boiler tersebut selanjutnya diadaptasi dengan konsep dasar fisika tentang suhu dan kalor. Pada silabus pembelajaran fisika tentang suhu dan kalor dibicarakan bagai mana proses perubahan suhu berhubungan dengan energy panas dan juga proses perpindahan energy panas itu sendiri. Ada 3 cara perpindahan panas, yakni; konduksi, konveksi dan radiasi, dimana ketiga proses perpindahan panas tersebut terjadi pada mesin boiler.

Untuk dapat mengilustrasikan prinsip kerja dari mesin boiler dan sesuai dengan konsep dasar fisika, dikembangkan model miniatur dalam bentuk simulasi sebagai multimedia pembelajaran. "Phet simulation" adalah salah satu bentuk multi media pembelajaran dengan memanfaatkan program computer dalam bentuk simulasi interaktif, program ini dapat diunduh melalui web Colorado University. Contoh dari simulasi ini dapat dilihat seperti pada Gambar 2.

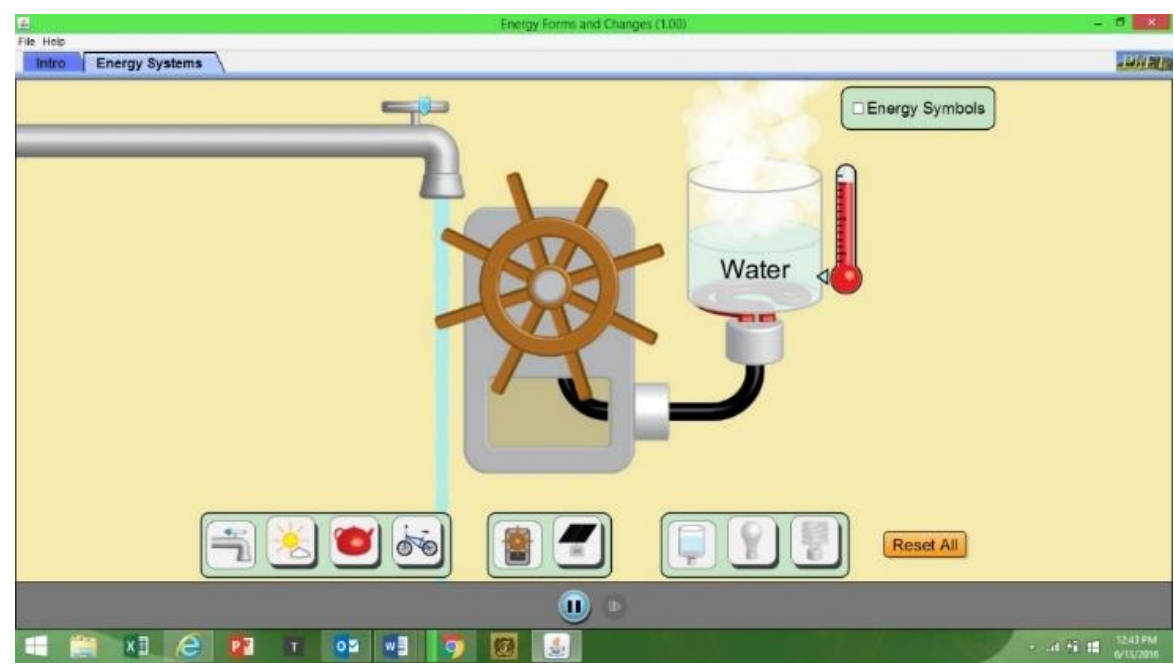

Gambar 2. Tampilan simulasi multimedia pembelajaran interaktif 
Formatif: Jurnal Ilmiah Pendidikan MIPA

Vol. 8, No. 2, Agustus 2018, pp. 129-142

p-ISSN: 2088-351X

e-ISSN: $2502-5457$

DOI: http://dx.doi.org/10.30998/formatif.v8i2.2407

\section{METODE}

Metodologi penelitian dalam kajian ini merupakan penelitian pengembangan (Research and Development, disingkat R \& D) dalam bidang pendidikan. Penelitian ini berfokus pada pengembangan program pembelajaran "FindBoiliQ" dengan pemanfaatan industri boiler sebagai objek belajar dan metode pembelajaran inquiry yang diitegrasikan pada Multi Media Interaktif sebagai pendekatan pada proses untuk meningkatkan prestasi belajar fisika di SMA pada konsep-konsep yang dianggap kompleks. Produk yang dihasilkan dari program pembelajaran ini adalah: 1) Bagan program pembelajaran "FindBoiliQ" lengkap dengan silabus dan rencana pembelajaran; 2) MMI konsep-konsep fisika SMA yang dianggap komplek; 3) Lembar Kegiatan Siswa untuk kegiatan pengamatan pada industri boiler; 4) alat ukur evaluasi proses dan hasil pembelajaran.

Penelitian ini menggunakan metode R \& D dengan menggunakan alur Model 4-D menurut Thiagarajan et al. (1974) yakni tahap pendefinisian (define), pendisainan (design), pengembangan (develop), dan diseminasi (diseminate) dengan penyesuaian seperlunya. Metode penelitian ini digunakan untuk menghasilkan produk (Astuti \& Bhakti, 2018). Penyesuaian tersebut meliputi analisis objek pembelajaran pada tahap pendefinisian, formulasi program pembelajaran dalam tahap pendesainan, penggabungan model 4-D dengan langkah-langkah pengembangan program pembelajaran berupa proyek pembuatan Multi Media Interaktif sebagai bagian dari miniatur objek dan Lembar Kerja Siswa. Pemilihan model 4-D sebagai metode R \& D dalam penelitian ini didasarkan atas pertimbangan efisiensi langkah bila dibandingkan dengan 10 langkah $\mathrm{R} \& \mathrm{D}$ model Borg \& Gall (1989), model 4-D dilengkapi dengan penjelasan yang relatif rinci pada setiap langkahnya. Tahap-tahap tersebut ditunjukkan dalam Gambar 3.

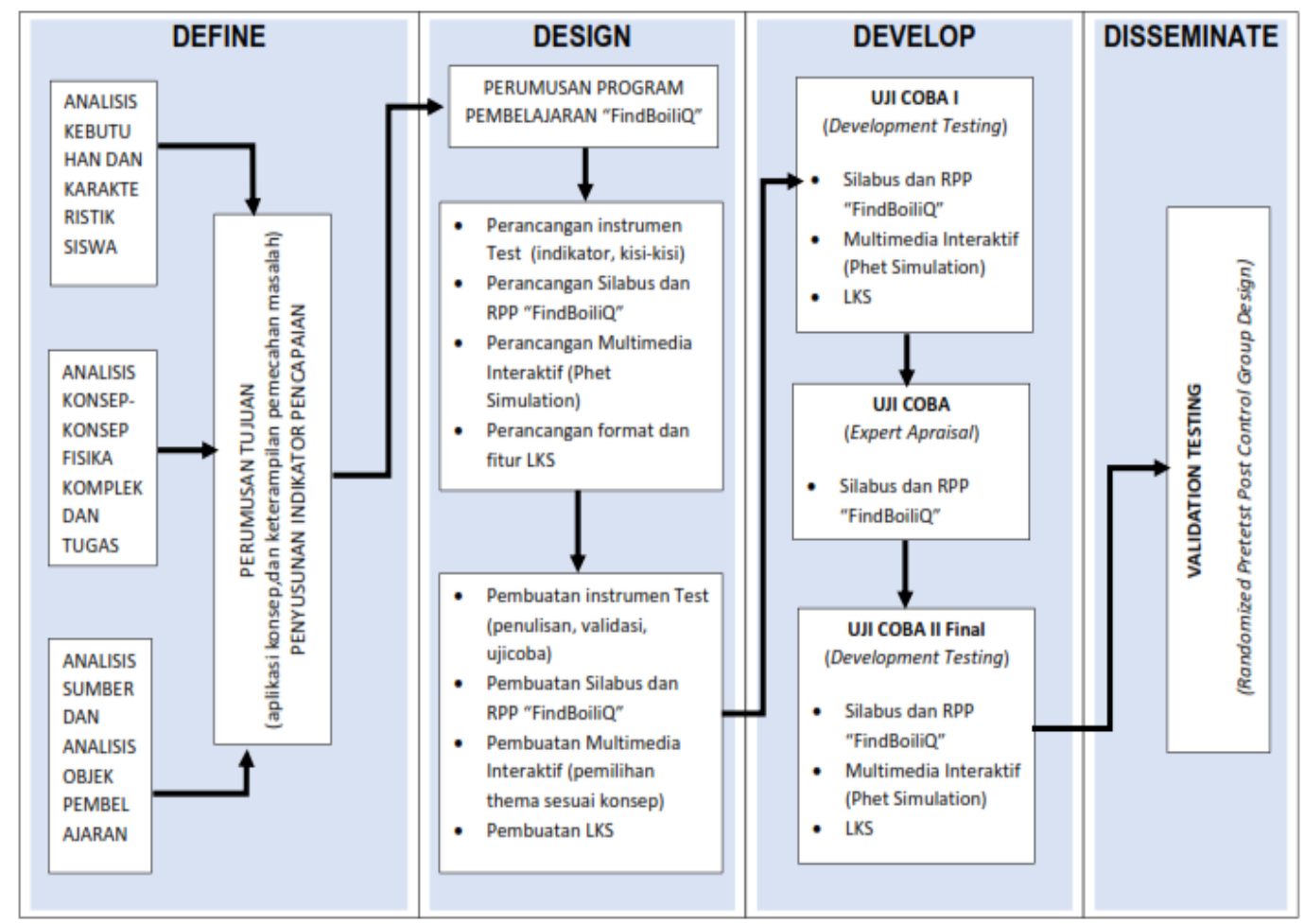

Gambar 3. Bagan Alir Rancangan R \& D 
Formatif: Jurnal Ilmiah Pendidikan MIPA

Vol. 8, No. 2, Agustus 2018, pp. 129-142

p-ISSN: 2088-351X

e-ISSN: 2502-5457

DOI: http://dx.doi.org/10.30998/formatif.v8i2.2407

\section{Desain}

Desain konstruksi dari kajian ini berdasarkan pada asumsi-asumsi. Asumsi pertama adalah bahwa proses dan hasil pembelajaran dipengaruhi oleh berbagai faktor eksternal dan internal. Asumsi ini untuk menjamin bahwa tindakan pembelajaran, dalam hal ini berupa proses pembelajaran fisika SMA dengan inquiry learning, berpengaruh terhadap hasil belajar siswa. Asumsi kedua adalah bahwa manusia adalah partisipan aktif dalam tindakan kognisinya sendiri. Dengan adanya asumsi ini, maka tindakan-tindakan siswa seperti kunjungan langsung pada objek pembelajaran, mempelajari konsep-konsep fisika melalui MMI, kegiatan diskusi, dan kegiatan pemecahan masalah menjadi dapat diterima sebagai tindakan kognisi, tidak sekedar tindakan fisik tanpa makna. Asumsi ketiga adalah bahwa perilaku pembelajaran fisika yang efektif dapat diidentifikasi dan hasilnya bersifat menetap pada diri siswa untuk jangka waktu tertentu. Asumsi ini untuk menjamin bahwa kajian untuk menemukan program pembelajaran yang efektif untuk tujuan-tujuan tertentu di dalam proses pembelajaran fisika SMA dimungkinkan. Asumsi keempat adalah keterampilan pemecahan masalah, dan kemampuan mengaplikasikan konsep sebagai hasil pembelajaran bersifat menetap pada diri siswa untuk jangka waktu tertentu, sehingga memungkinkan untuk diukur. Asumsi ini digunakan sebagai penanda area kajian ini, yakni berada pada wilayah positivisme (kuantitatif). Berdasarkan empat asumsi tersebut, maka disusunlah desain penelitian ini, seperti ditunjukkan dalam Gambar 4.

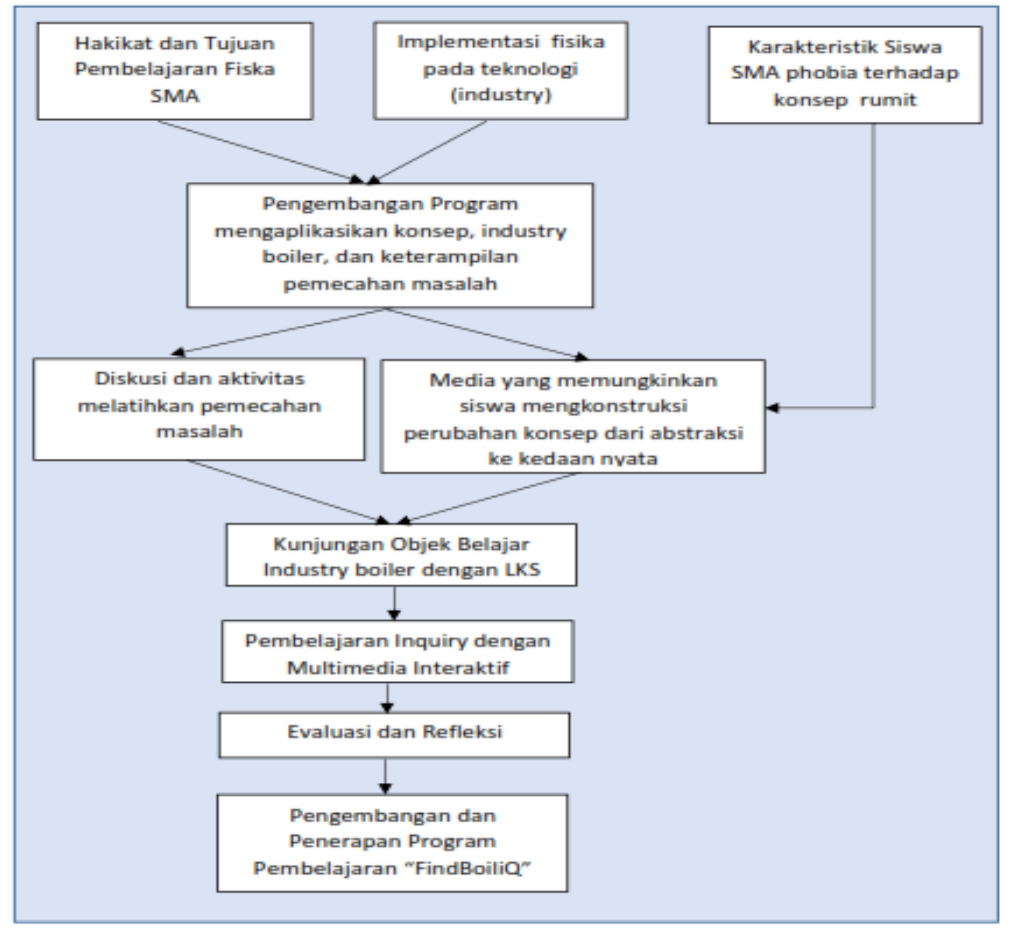

Gambar 4. Desain Kajian Program Pembelajaran

Gambar 4 menunjukkan bahwa terdapat tiga aspek yang diyakini sebagai corak dan menentukan tujuan dari program pembelajaran ini. Ketiga aspek yang menjadi corak dan menentukan tujuan adalah adanya perbedaan karakteristik pada setiap individu siswa, 
Formatif: Jurnal Ilmiah Pendidikan MIPA

Vol. 8, No. 2, Agustus 2018, pp. 129-142

p-ISSN: 2088-351X

e-ISSN: 2502-5457

DOI: http://dx.doi.org/10.30998/formatif.v8i2.2407

terdapat implementasi fiska dalam penerapan teknologi dan industry, dan hakekat serta tujuan dari proses pembelajaran fisika SMA. Berdasarkan ketiga aspek tersebut, didapatkan bahwa tujuan dari proses pembelajaran fisika adalah memberikan pemahaman pengetahuan untuk meningkatkan keterampilan pemecahan masalah, serta peningkatan pemahaman terhadap konsep-konsep fisika yang banyak aplikasinya dalam kehidupan sehari-hari.

Desain kajian ini menyatakan, untuk mencapai ketiga tujuan tersebut dilakukan proses pembelajaran fisika yang memanfaatkan industry boiler sebagai objek pembelajaran dimana siswa dapat melihat secara langsung bagaimana aplikasi fiska diterapkan, dialnjutkan dengan kekuatan Multimedia Interaktif untuk konstruksi individual terhadap konsep-konsep dasar fisika sebagai landasan untuk pemecahan masalah yang dapat dilakukan "kapan saja" dan "di mana saja", adanya latihan memecahkan masalah dan diskusi hasil pengamatan adalah pembelajaran yang dilakukan secara secara kolaboratif, dan adanya kesempatan siswa untuk melakukan evaluasi terhadap apa yang telah dilakukan dan dipelajari juga menjadi elemen penting dalam program pembelajaran ini.

Ketiga elemen pembelajaran tersebut, yakni Industry boiler, Multimedia Interaktif dengan pendekatan inquiry learning, dan keterampilan pemecahan masalah sebagai evaluasi, merupakan elemen-elemen dasar dari program pembelajaran "FinBoiliQ". Desain ini menunjukkan bahwa program pembelajaran "FindBoiliQ" digunakan untuk meningkatkan keterampilan pemecahan masalah, dan pengetahuan knsep siswa melalui aplikasi konsep fisika dalam teknologi dan industry yang bermanfaat dalam kehidupan sehari-hari. Berdasarkan desain tersebut, diperlukan metode untuk melakukan kajian untuk mengembangkan program pembelajaran "FindBoiliQ" dalam kegiatan belajar fisika SMA, serta menguji efektivitas program pembelajaran "FindBoiliQ" dalam meningkatkan ketiga tujuan tersebut.

\section{Setting}

Variabel-variabel dalam penelitian ini yang menjadi inti kajian adalah program pembelajaran "FindBoiliQ", keterampilan pemecahan masalah, dan kemampuan mengaplikasikan konsep-konsep fisika. Agar terjadi pemahaman konsep yang sama mengenai berbagai istilah dalam variabel-variabel tersebut dan sebagai pedoman dalam penyusunan alat pengumpulan data, maka variabel-variabel tersebut perlu didefinisikan secara operasional.

Program "FindBoiliQ" didefinisikan sebagai pola atau desain konsep, langkahlangkah, dan lingkungan pembelajaran yang disusun dengan memanfaatkan Industry boiler sebagai objek pembelajaran, elemen-elemen Multimedia Interaktif dengan Inquiry learning, diskusi kolaboratif, dan evaluasi sehingga memungkinkan terjadinya proses pembelajaran pada siswa untuk mencapai tujuan pembelajaran yang berupa keterampilan pemecahan masalah, dan aplikasi konsep. Keterampilan pemecahan masalah adalah keterampilan menerapkan langkah-langkah pemecahan masalah yang ditunjukkan oleh skor tes keterampilan pemecahan masalah atau skor penilaian kinerja untuk keterampilan pemecahan masalah. Kemampuan mengaplikasikan konsep-konsep fisika merupakan kemampuan untuk menggunakan konsep-konsep, prinsip-prinsip, atau hukum-hukum fisika ke dalam situasi baru yang konkrit yang ditunjukkan oleh skor tes aplikasi konsep fisika. 
Formatif: Jurnal Ilmiah Pendidikan MIPA

Vol. 8, No. 2, Agustus 2018, pp. 129-142

p-ISSN: 2088-351X

e-ISSN: 2502-5457

DOI: http://dx.doi.org/10.30998/formatif.v8i2.2407

\section{Populasi}

Kajian dilakukan di SMA Al-Azhar Harapan Indah Kota Bekasi Jawa-Barat sebagai tempat pengambilan data, dan di SMA Negeri 4 Kota Bekasi sebagai tempat pusat kegiatan MGMP Fisika untuk perancangan kajian, pengembangan instrumen, analisis data, dan penyusunan laporan hasil kajian. Pemilihan tempat pengambilan data pada lokasi tersebut didasari pertimbangan bahwa SMA Al-Azhar Harapan Indah adalah sekolah yang memiliki latar belakang yayasan pengembangnya merupakan bagian dari kelompuk usaha industry (NWI-Group) yaitu industry boiler yang menjadi objek pembelajaran. Populasi kajian ini adalah seluruh siswa SMA Al-Azhar Harapan Indah Kelas 10 dan 11 Program MIA dari tahun pelajaran 2017/2018. Sampel dipilih dengan teknik purposive sampling.

\section{Validasi dan Reliabilitas}

Kajian ini dilakukan dalam 4 tahap, sesuai dengan tahapan-tahapan dalam model 4-D. Setiap tahapnya (kecuali tahap pendisainan) memerlukan teknik serta alat pengumpulan data yang sesuai. Tabel 1 , menunjukkan teknik dan alat pengumpulan data yang digunakan.

Tabel 1. Teknik dan Alat Pengumpulan Data pada Setiap Tahap Penelitian

\begin{tabular}{|c|c|c|c|}
\hline Tahap & Data yang Diperlukan & $\begin{array}{c}\text { Teknik } \\
\text { Pengumpulan } \\
\text { data }\end{array}$ & $\begin{array}{l}\text { Alat Pengumpulan } \\
\text { Data }\end{array}$ \\
\hline \multirow[t]{2}{*}{ Pendefinisian } & Karakteristik Siswa & Studi dokumen & - \\
\hline & $\begin{array}{l}\text { Fasilitas dan Objek } \\
\text { pembelajaran }\end{array}$ & Observasi & $\begin{array}{l}\text { Panduan } \\
\text { Observasi }\end{array}$ \\
\hline \multirow[t]{5}{*}{ Pengembangan } & $\begin{array}{l}\text { Kualitas perencanaan program } \\
\text { pembelajaran "FindBoiliQ }\end{array}$ & Penilaian ahli & Rubrik \\
\hline & Kualitas MMI & Penilaian ahli & Rubrik \\
\hline & Kualitas LKS & Penilaian ahli & Rubrik \\
\hline & $\begin{array}{l}\text { Tanggapan siswa terhadap } \\
\text { MMI }\end{array}$ & Kuesioner & $\begin{array}{l}\text { Angket dengan } \\
\text { pertanyaan } \\
\text { tertutup }\end{array}$ \\
\hline & $\begin{array}{l}\text { Tanggapan siswa terhadap } \\
\text { LKM dan pelaksanaannya }\end{array}$ & Kuesioner & $\begin{array}{l}\text { Angket dengan } \\
\text { pertanyaan } \\
\text { terbuka }\end{array}$ \\
\hline \multirow[t]{5}{*}{$\begin{array}{l}\text { Diseminasi } \\
\text { (Validasi Model) }\end{array}$} & $\begin{array}{l}\text { Aktivitas pembelajaran } \\
\text { "FindBoiliQ" }\end{array}$ & Observasi & Lembar Observasi \\
\hline & $\begin{array}{l}\text { Keterampilan pemecahan } \\
\text { masalah }\end{array}$ & Tes & Tes pilihan ganda \\
\hline & & Penilaian Produk & Rubrik \\
\hline & $\begin{array}{l}\text { Kemampuan aplikasi konsep } \\
\text { fisika }\end{array}$ & Tes & Tes pilihan ganda \\
\hline & $\begin{array}{l}\text { Tanggapan siswa terhadap } \\
\text { proses pembelajaran dengan } \\
\text { Program Pembelajaran } \\
\text { "FindBoiliQ" }\end{array}$ & Kuesioner & $\begin{array}{l}\text { Angket dengan } \\
\text { pertanyaan } \\
\text { terbuka }\end{array}$ \\
\hline
\end{tabular}


Formatif: Jurnal Ilmiah Pendidikan MIPA

Vol. 8, No. 2, Agustus 2018, pp. 129-142

p-ISSN: 2088-351X

e-ISSN: 2502-5457

DOI: http://dx.doi.org/10.30998/formatif.v8i2.2407

\section{Lembar Pengamatan}

Lembar pengamatan terhadap aktivitas proses pembelajaran meliputi Lembar Pengamatan Keterlaksanaan Rencana Pelaksanaan Pembelajaran (RPP) dan Lembar Pengamatan Proses Pembelajaran. Kedua lembar pengamatan tersebut digunakan untuk mengetahui kualitas keterlaksanaan proses pembelajaran dengan program pembelajaran "FindBoiliQ" dan aktivitas-aktivitas siswa selama mengikuti kegiatan pembelajaran. Pengamatan dilakukan oleh pengamat yang sudah dilatih sehingga dapat mengoperasikan lembar pengamatan secara benar.

Intrumen pengamatan menggunakan kriteria reliabilitas yakni instrumen lembar pengamatan dikatakan reliabel jika $R \geq 0,75$. Pengembangan instrumen lembar pengamatan keterlaksanaan RPP.

\section{Tes}

Tes dalam kajian ini meliputi tes keterampilan pemecahan masalah, dan aplikasi konsep. Tes keterampilan pemecahan masalah dikembangkan berdasarkan indikator pemecahan masalah. Tes kemampuan aplikasi konsep dikembangkan berdasarkan indikator aplikasi konsep. Tes dikembangkan pada ruang lingkup konsep suhu, kalor, dan perpindahan kalor.

Untuk menilai kesesuaian antara indikator dengan butir tes yang dikembangkan dilakukan validasi. Validasi tersebut mencakup validitas isi (kesesuaian tes dengan materi atau isi pelajaran Fisika), validitas konstruksi (kesesuaian butir tes untuk mengukur aspek berpikir sesuai dengan indikator), dan validitas muka (penilaian terhadap penampilan tes). Validasi isi terutama dari sisi kriteria penilaian dari sisi konsep, meliputi butir tes berada di dalam lingkup konsep yang didefinisikan dan kebenaran konsep. Validasi konstruksi meliputi penilaian terhadap keseuaian butir tes dengan indikator keterampilan pemecahan masalah. Validitas muka dinilai dari sisi letak permasalahan di tiap butir tes, kalimat mudah dimengerti, tidak mengandung pemborosan kata-kata, dan relevansi pengecoh. Penilai ahli untuk keperluan validasi ini berasal ahli fisika, serta ahli pengukuran dan evaluasi pendidikan fisika. Selain melakukan penilaian, para ahli melakukan koreksi jika diperlukan, langsung pada lembar tes yang dinilai tersebut.

Validitas butir tes ditujukan untuk mengetahui seberapa jauh hubungan antara jawaban pada suatu butir tes yang diskor secara dikotomi dengan skor tes total. Validitas butir tes dihitung dengan cara menguji-korelasikan skor butir terhadap skor total. Dalam kajian ini uji korelasi dilakukan dengan korelasi Pearson atau koefisien korelasi productmoment .

Penggunaan alfa Cronbach untuk penentuan reliabilitas dengan pertimbangan bahwa model ini mendasarkan pada konsistensi internal tes yang berdasarkan korelasi rerata antar item dan mudah dilakukan, dan merupakan prosedur statistik yang paling lazim untuk mengestimasi reliabilitas dari sisi konsistensi internal. Perhitungan korelasi alfa Cronbach dilakukan dengan bantuan SPSS versi akhir, sedangkan kriteria reliabilitas menggunakan intrepretasi besar koefisien korelasi menurut Arikunto (1991).

Butir tes dianalisis pula berdasarkan taraf kesukaran butir dan daya pembeda butir. Taraf kesukaran butir merupakan perbandingan antara banyaknya peserta tes yang menjawab benar dengan jumlah seluruh peserta tes (Arikunto, 1991). Dengan analisis ini akan diketahui apakah soal tersebut berkategori mudah, sedang, atau sukar. Kriteria yang digunakan adalah klasifikasi kesukaran soal berdasarkan tingkat kesukaran menurut Arikunto (1991). Daya pembeda ditentukan dengan mengurangi proporsi kelompok atas yang menjawab benar dengan proporsi kelompok bawah yang menjawab benar dari suatu 
Formatif: Jurnal Ilmiah Pendidikan MIPA

Vol. 8, No. 2, Agustus 2018, pp. 129-142

p-ISSN: 2088-351X

e-ISSN: 2502-5457

DOI: http://dx.doi.org/10.30998/formatif.v8i2.2407

butir tes. Dengan analisis ini akan diketahui apakah soal tersebut memiliki daya pembeda yang baik atau jelek. Kriteria yang digunakan adalah klasifikasi daya pembeda soal menurut Arikunto (1991).

\section{Analisis data}

Teknik analisis data dalam kajian ini secara umum meliputi analisis deskriptif dan inferensial. Analisis deskriptif dilakukan untuk mendiskripsikan data dari angket, pengamatan, dan rubrik, dilakukan secara kualitatif dalam bentuk deskripsi informasi berdasarkan kategori tertentu serta dalam bentuk kuantitatif yang berupa persentase, ratarata, dan simpangan baku dari data. Analisis inferensial digunakan untuk mengetahui efektivitas program pembelajaran.

Uji perbedaan dua rerata dari dua sampel independen dengan uji $U$ MannWhitney dilakukan untuk mengetahui apakah antara kelompok eksperimen dan kelompok kontrol terdapat perbedaan N-Gain (gain ternormalisasi).

\section{HASIL DAN PEMBAHASAN}

Hasil

Penelitian diawali dengan memberikan soal tes penalaran ilmiah kepada siswa kelas eksperimen dan kelas kontrol. Hasil tes digunakan untuk mengelompokkan siswa menjadi kelompok siswa konvensional dan siswa implemntasi. Program Finboiliq diawali dengan pemberian permasalahan pada siswa. Permasalahan dipakai untuk mengetahui konsep yang dianggap kompleks oleh siswa. Selanjutnya guru bersama dengan siswa melaksanakan aktivitas kunjungan pada objekpembelajaran yang merupakan implemntasi konsep dalam kehidupan sehari-hari, melalui demonstrasi Multi Media Interaktif pemahaman kognitif siswa dikuatkan untuk menuntun siswa ke arah perubahan konsep yang benar. Diskusi lebih lanjut memberi kesempatan kepada siswa untuk membandingkan analisis mereka dengan sebuah analisis ilmiah, tentunya panduan lembar kerja siswa yang telah disiapkan.

Berdasarkan hasil pengamatan, kemampuan penalaran ilmiah berperan aktif dalam proses pembelajaran strategi inquiry. Siswa Implemnatasi melalui proses pembelaajran findboiliq memiliki pemahaman konsep yang lebih dalam dan lebih cepat untuk mengikuti pembelajaran dibandingkan siswa konvensional, terutama pada saat menyelesaikan suatu masalah.

Data kemampuan penalaran ilmiah siswa yaitu bagaimana mereka memahami konsep sesuai dengan alur berpikir mereka secara keseluruhan baik siswa dari kelas Implementasi maupun siswa dari kelas Konvensional diperoleh sebelum siswa mendapat perlakuan. Sekor hasil tes kemampuan penalaran ilmiah ditunjukkan pada Tabel 2.

Tabel 2. Deskripsi Data Penalaran Ilmiah

\begin{tabular}{lccccc}
\hline & $\mathrm{N}$ & Mean $(\bar{x})$ & Std. Dev $(\mathrm{s})$ & Minimum & Maksimum \\
\hline $\begin{array}{l}\text { Penalaran Ilmiah } \\
\text { Kelas Implementasi }\end{array}$ & 105 & 11,97 & 2,24 & 5 & 15 \\
\hline $\begin{array}{l}\text { Penalaran Ilmiah } \\
\text { Kelas Konvensional }\end{array}$ & 105 & 10,51 & 2,17 & 7 & 15 \\
\hline Total & & 11,24 & 2,21 & 6,50 & 15 \\
\hline
\end{tabular}


Formatif: Jurnal Ilmiah Pendidikan MIPA

Vol. 8, No. 2, Agustus 2018, pp. 129-142

p-ISSN: 2088-351X

e-ISSN: 2502-5457

DOI: http://dx.doi.org/10.30998/formatif.v8i2.2407

Data penguasaan konsep yaitu pemahaman siswa terhadap materi yang sedang mereka pelajari sesuai dengan teori dasar untuk setiap kelas implementasi sebagai kelas eksperimen dan kelas konvensional sebagai kelas kontrol diperoleh sesudah perlakuan program. Skor penguasaan konsep ditunjukkan pada Tabel 3.

Tabel 3. Deskripsi Data Penguasaan Konsep

\begin{tabular}{lccccc}
\hline & $\mathrm{N}$ & Mean $(\bar{x})$ & Std. Dev (s) & Minimum & Maksimum \\
\hline $\begin{array}{l}\text { Penguasaan Konsep } \\
\text { Kelas Implementasi }\end{array}$ & 44 & 21,31 & 1,84 & 18 & 24 \\
\hline $\begin{array}{l}\text { Pengusaan Konsep } \\
\text { Kelas Konvensional }\end{array}$ & 42 & 18,23 & 1,49 & 16 & 21 \\
\hline Total & 86 & 19,77 & 1,66 & 17 & 22,5 \\
\hline
\end{tabular}

\section{Pembahasan}

Nilai dari siswa yang belajar dengan menggunakan model pembelejaran FindBoiliQ atau kelas implementasi lebih tinggi dibandingkan dengan siswa yang belajar secara konvensional pada tingkat pemahaman konsep. Hal ini dikarenakan pemahaman konsep siswa kelas Implementasi mendapatkan penekanan pada aktivitas diskusi dan kunjungan objek belajara langsung aplikasi konsep pada kehidupan seharia-hari, dan ditunjang dengan bantuan tutorial melalui Multi Media Interaktif. Hasil ini sesuai dengan yang disampaikan Downey 1967 dalam Joyce (2003) menyatakan bahwa inti dari berpikir yang baik adalah kemampuan untuk memecahkan masalah. Dasar dari pemecahan masalah adalah kemampuan untuk belajar dalam situasi proses berpikir. Oleh sebab itu, nilai penguasaan konsep siswa yang belajar menggunakan implementasi FindBoiliQ pemahaman kognitifnya lebih baik daripada siswa yang belajar secara konvensional. Siswa yang belajar dengan cara konvensional belajar dengan menggunakan model ceramah cenderung linier lebih lama mengambil infomasi yang diperolehnya. Pembelajaran yang mengkondisikan siswa untuk menggali pengetahuan dan mengaitkannya pada konsep dasar, berdampak pada peningkatan perkembangan pengetahuan yang lebih pada siswa pada tingkat kemampuan penalaran ilmiah yang tinggi.

\section{PENUTUP}

Berdasarkan hasil deskripsi pembelajaran, deskripsi penalaran konsep, dan deskripsi penguasaan konsep secara keseluruhan program pembelajaran FindBoiliq telah diimplementasikan dan mendapatkan simpulan sebagai berikut:

1. Penalaran ilmiah sebelum pelaksanaan pembelajaran Findboiliq antara kelas implementasi yang akan menjalankan program pembelajaran sebagai kelas eksperimen cenderung sama dibandingkan dengan kelas konvensional yang akan menjalankan pembelajaran reguler sebagai kelas kontrol,

2. Penguasaan konsep fisika pada konsep yang dianggap komplek kelas implementasi yang menjalankan program pembelajaran sebagai kelas eksperimen lebih baik dibandingkan dengan kelas konvensional yang mejalankan pembelajaran reguler sebagai kelas konrol,

3. Pembelajaran Finboiliq sebagai bentuk pengembangan pembelajaran fisika pada konsep konsep yang dianggap komplek oleh siswa cukup efektif meningkatkan 
Formatif: Jurnal Ilmiah Pendidikan MIPA

Vol. 8, No. 2, Agustus 2018, pp. 129-142

p-ISSN: 2088-351X

e-ISSN: 2502-5457

DOI: http://dx.doi.org/10.30998/formatif.v8i2.2407

penguasaan konsep fisika siswa pada kondisi ini. Hal ini ditunjukkan oleh hasil keseluruhan antara siswa kelas implementasi dan kelas konvensional sebagai kelas eksperimen dan kelas kontrol.

4. Kelemahan dari Finboiliq adalah bersifat terbatas pada konsep-konsep fisika yang telah ada bentuk pemanfaatannya dalam kehidupan sehari-hari terutama dalam pengmebangan industri strategis.

Pengembangan model pembelajaran terus dilanjutkan untuk dapat menyelsaikan semua konsep yang sering dianggap komplek oleh siswa dalam memahami secara lebih dalam dan lebih baik. Saran pengembangan dilakukan pada implementasi objek pembelajaran selain pada industri yang sudah ada.

\section{DAFTAR PUSTAKA}

Arikunto, Suharsimi. (1991). Dasar-dasar Evaluasi Pendidikan. Jakarta: Bina Aksara.

Astuti, I. A. D., \& Bhakti, Y. B. (2018). Interactive Learning Multimedia Based Microsoft Excel On The Temperature And Heat. Unnes Science Education Journal, 7(1).

Bhakti, Y. B., \& Napis, N. (2017). Kemampuan Mahasiswa Pendidikan Fisika dalam Menyelesaikan Soal Ujian Nasional Fisika SMA Ditinjau dari Daerah Sekolah Asal. Jurnal Riset dan Kajian Pendidikan Fisika, 4(1), 25-30.

Borg, W.R. \& Gall, M. D. (1989). Educational Research. New York: Longman.

Joyce, B., Weil, M., \& Calhoun, E. (2003). Models of teaching.

Mulyasa. (2008). Menjadi Guru Profesional Menciptakan Pembelajaran Kreatif dan Menyenangkan. Bandung: Remaja Rosdakarya.

Redish, E. F. (2004). A theoritical Framework for physics education research: Modeling student thinking. In Redish, E.F. \& Vicentini, M. (Ed.) Ricerca in didattica della fisica. Bologna: Societa Italiana di Fisica.

Rutherford, F.J. \& Ahlgren, A. (1990). Science for All Americans. New Yok: Oxford University Press.

Sanjaya, Wina. (2007). Kajian Kurikulum dan Pembelajaran. Bandung: Sekolah Pascasarjana UPI.

Thiagarajan, S., Semmel, D. S. \& Semmel, M. (1974). Instructional Development for Training Teachers of Exceptional Children. Source Book. Bloominton: Center for Innovation on Teaching the Handicapped.

Tipler, Paul A. (1991). FISIKA untuk Sains dan Teknik. Jakarta: Erlangga.

Wenning, C. J. (2011). Levels of Inquiry Model of Science Teaching: Learning sequences to lesson plans. Journal of Physics Teacher Education Online, 6(2): 17-20.

Wospakrik. J.H. (1993). Dasar-dasar Matematika Untuk Fisika. Indonesia. ITB PressBandung. 
Formatif: Jurnal Ilmiah Pendidikan MIPA

Vol. 8, No. 2, Agustus 2018, pp. 129-142

p-ISSN: 2088-351X

e-ISSN: 2502-5457

DOI: http://dx.doi.org/10.30998/formatif.v8i2.2407

(2) $\odot \Theta \Theta$ 